\title{
Arbitration on Unauthorized Trades by the Trading Member of the Stock Exchange: An Empirical Study
}

\author{
Dr. B. Brahmaiah \\ ICFAI Business School, IFHE, Hyderabad, India \\ Email: brahmaiahb@ibsindia.org, brahmaiahb@yahoo.com
}

How to cite this paper: Brahmaiah, Dr.B. (2017) Arbitration on Unauthorized Trades by the Trading Member of the Stock Exchange: An Empirical Study. Theoretical Economics Letters, 7, 1557-1567. https://doi.org/10.4236/tel.2017.76105

Received: July 1, 2017

Accepted: September 5, 2017

Published: September 8, 2017

Copyright $\odot 2017$ by author and Scientific Research Publishing Inc. This work is licensed under the Creative Commons Attribution International License (CC BY 4.0).

http://creativecommons.org/licenses/by/4.0/ (c) (i) Open Access

\begin{abstract}
This case is an appeal matter with the Stock Exchange on the award passed by the sole arbitrator with regard to a dispute between a client and trading member of the Stock Exchange. Mumbai Capitals Ltd. contended that the award passed by the arbitrator did not take into account of the evidences, supported documents and rules of stock exchange appropriately while determining the case matter and passing the award. Appellant challenged the Award on grounds that the award was beyond the scope of submissions to the arbitration, pre-mediated conclusion, non-application of mind, ignorance of established judicial principles, and misreading of the provisions of stock exchange. The Appellate Tribunal had to determine whether there had been any lapses on the part of the arbitrator in applying the trading rules and procedures of the exchange while analyzing the matter, determining the case and passing the award. Based on that, the Appellant Arbitral Tribunal had to decide whether to set aside the award passed by sole arbitrator, modify the award or uphold it.
\end{abstract}

\section{Keywords}

Arbitration, Trading Member, Appellant, Respondent, Stock Exchange

\section{Introduction}

This is an appeal matter filed by the Mumbai Capitals Ltd. (MCL) against the award passed by the sole Arbitrator with regard to a complaint of Mr NS Rao, client, against Mumbai Capitals Ltd., regarding a dispute on unauthorized trades carried out by the trading member, Mumbai Capitals Ltd. (MCL) on the trading system of the Stock Exchange (SEBI 2010) [1]. MCL is a trading member of Stock Exchange, the leading stock exchange in India. Incorporated under the 
Companies Act, 1956, it was one of the leading stock broking companies in India. MCL had grown from a standalone brokerage firm into a multiproduct and service company over a period of 30 years. It provides a comprehensive gamut of financial advisory services to institutional and individual clients. With a team of dedicated experts and a nationwide distribution network of branches, franchisees, and associates, the range of services, it provided broking, investment banking, and corporate advisory and portfolio management services. Mr NS Rao is a registered client with MCL for trading and investment in securities. He was in the business of trading i.e., buying and selling of securities for the last ten years.

\section{Personal Appearance and Hearings}

Hearing for this matter was held at the Regional Arbitration Centre, Hyderabad. The Appellant, Mumbai Capitals Ltd, was represented by Mr David John, Chief Financial Officer, Mumbai Capitals, and the Respondent, Mr NS Rao appeared along with his wife, Mrs. Lakshmi. Both the parties argued their respective cases and declared that they had nothing more to submit, and upon this, the matter was reserved for pronouncement of Arbitral Award. Appellant was directed to provide evidence of call data/record of calls between the Respondent and Appellant within a month's time. Appellant requested further extension of time till end of the month. Accordingly, time was extended as requested by the MCL to submit the information. After going through the records, documents, submissions and evidences placed before this Appellant Tribunal and hearings of both the parties, passed the Arbitral Award according to the Arbitration and Conciliation Act, 1996 [2].

\section{Contentions of the Parties before the Sole Arbitrator}

The sole arbitrator found that there was no merit in sanctioning various reliefs and prayer for the setting aside the "Order" of the Investor Grievance Resolution Panel (IGRP) Member as sought by the Applicant. The sole Arbitrator concluded that there had been lack of transparency and suppression of information on the part of the Applicant and it had failed to substantiate its claim that orders were placed by the Respondent. It was a clear case of illegal and unauthorized trading in the account of Respondent, which was not properly investigated and prima facie overlooked by the Applicant. The Arbitrator found that these were unauthorized trades and even if these were communicated subsequently to the Respondent, these would not be regular trades. Applicant could not produce any evidence or voice records that these orders were placed by the Respondent. The Arbitrator found that the Applicant had neglected the ethics and responsibility to protect the interest of its client, as prescribed by the Securities and Exchange Board of India (SEBI 2012) [3] and Stock Exchange. The Arbitrator concluded that there was neither suitable complaints resolution mechanism nor effective surveillance system to monitor unauthorized trades executed by its dealers.

There was no convincing answer to the emails dated $4^{\text {th }}$ March, 2013, and $19^{\text {th }}$ 
July 2013 of Respondent to the Applicant. There was no reliable explanations and answers to the two pay out cheques of 31-03-2012 and 31-03-2013. Two cheques were credited to the Respondent's account on respective dates amounting Rs 550,000 dated 31-03-2012 and Rs 800,000 dated 31-03-2013 and these entries were reversed by the Appellant on 2-04-2012 and 2-04-2013 respectively under reason and remark that these were returned by the Respondent. It was concluded that the MCL was not able to produce any evidence that these cheques were actually dispatched to the Respondent on 31-03-2012 and 31-03-2013 or not and how both the cheques were returned. On the basses of these, the Arbitrator passed an award directing Mumbai Capitals Ltd to pay an amount of Rs 2,796,260 (Rupees twenty seven lakhs, ninety six thousand, two hundred and sixty only) after adjusting pay out amount of Rs 703,730 to the Respondent.

\section{Contentions of the Parties before the Appellant Tribunal}

\subsection{Statement of Claim by the Appellant}

The Appellant appealed against the Award passed by the sole Arbitrator and challenged the Award on following grounds. The award was based on beyond the scope of submissions to the arbitration, pre mediated conclusion, non application of mind, ignorance of established judicial principles, misreading of the provisions of NSE, incorrect readings of submissions made by the Appellant and also in undue haste. Appellant also contended that the impugned award which was a non speaking award and erroneous and bad in law. Appellant raised similar objections on the order passed by the IGRP Member. Appellant appealed against the award and submitted the following contentions, and objections in its submissions. The Appellant submits that the Respondent Mr NS Rao is a constituent and opened an account for trading in cash and derivative segments of the National Stock Exchange (NSE) and Bombay Stock Exchange Ltd. (BSE). Appellant reported that Respondent also executed several mandatory and non mandatory documents along with Know Your Client (KYC) documents with the Appellant. Appellant confirmed that Respondent issued a cheque for Rs 500,000 on November 25, 2011 towards subscription fees to avail of brokerage services and charges and duly executed cost of subscription sheet. Respondent opted to avail of services on online trading through the Appellant's trading system. The Respondent transferred Rs 3,000,000 through RTGS on November 26, 2011 to the Appellant's Bank account towards cash and initial margins before initiating trades in Futures and Options segment on November, 28, 2011.

The Appellant submitted that the confirmations were sent to the Respondent regularly and all other information about trades, contract notes, margin statements, ledger balances, details of short fall in margins, etc through emails. Thus the Appellant had in compliance with its duty towards Respondent. The Appellant reiterated that it had neither received any complaint regarding non receipt contract notes nor related to trades being unauthorized. Appellant made two pay outs as sought by the Respondent. One cheque bearing no 073594 for an amount 
Rs 400,000 was issued on December 2, 2011 and another cheque bearing No 299298 dated 3-02-2012 for an amount of Rs 1,200,000 was issued to the Respondent towards pay outs as requested by the Respondent. The Appellant contended that the Respondent was in an attempt to circumvent his liability to bear the losses incurred in his account with his trades and as an afterthought he filed belated complaint with the Investor Services Cell of the Exchange on May 12, 2015 and June 1, 2015 almost after three years of the last trade. The complaint was duly replied and denied all allegations raised by the Respondent. The matter was referred to the IGRP Member and the IGRP Member passed an order, while admitting part claim of Respondent and directed the MCL to pay Rs 1,750,000 being fifty per cent of claim. Appellant contended that the IGRP Member passed an order without considering the submissions and documentary evidences put forth by the Appellant. The Appellant being aggrieved by the order and referred the matter to Arbitration of the Exchange. The sole Arbitrator was appointed by the NSE and the Arbitrator after duly conducting the arbitration proceedings, passed an award on October 6, 2015 directing the MCL to pay a sum of Rs 2,796,260 after adjusting the pay outs to the Respondent. The Appellant again being aggrieved by the award of the sole Arbitrator and appealed the matter to Appellate Tribunal, which consists of three arbitrators while claiming that the impugned award, suffers from the defects and flaws.

\subsection{Submissions by the Respondent}

Respondent alleged that the trades and transactions carried out by the Appellant were unauthorized. Respondent submitted that the account transaction summary provided by the Appellant, was showing two different credit entries on March 31, 2012 and March 31, 2013 and two debit entries on April 2, 2012 and April 2, 2013. Respondent submitted that Appellant claimed that this happened on account of two cheques bearing no 74689 dated 31/03/2012 and bearing no 497727 dated 31/03/2013 were dispatched to the Respondent and these were returned by the Respondent within two days. These entries were reversed on 2-04-2012 and 02-04-2013. According to the Respondent, it was completely false and highly objectionable. Neither he received these two cheques nor did he return them. These entries were falsely created to make zero balancing of his account at the end financial years 2012 and 2013 to comply with the NSE's requirements. This was to be treated as breach of law and cheating. Respondent sent multiple emails to all the relevant addressees of MCL regarding refund of his deposit. Respondent stated that the staff members of MCL requested for more time to recover his losses itself are a proof that none of the transaction was executed with his instructions and consent. The telephone conversation between Mumbai Capitals' staff and him was provided by him in a compact disk (CD) where the staff himself accepted the mistake on their part and asked for some more time to recover the losses incurred in his account by their expert team members. Had the transactions been instructed by him, why would Mumbai 
Capitals staff ask for more time? The staff members of the MCL confirmed in writing through their emails dated April 11 and April 12 and June 16, 2012. There were no transactions/trades after their e-mails.

All these logins in the online account are prior to market hours and doesn't involve any trades. Remaining logins are from the IP address of Mumbai server which is evident that the IP belongs to Mumbai Capitals. The logins are more than sufficient to prove and conclude that they are fraud and indulged in unethical business practices. All the possible efforts were made to retrieve his deposit from MCL until Dec 2013. All the allegations made by the Appellant were rejected and objected by the Respondent. The Appellant is confused and trying to confuse the panel members and by its irrelevant answers, stated by the Respondent. The Respondent prays for the refund of his deposit of Rs. 3,500,000 with reasonable interest from November 2011 from Mumbai Capitals. Respondent also prayed for levy of penalty for misappropriating his money and also levy penalty charges compensate the struggle, stress and the mental agony caused to him and his family.

\section{Findings, Observations and Conclusions}

The Respondent (Client) had not carried out due diligence about the Appellant and its activities and made the payment of Rs 3,500,000 to MCL for trading. No authentic and verifiable evidence was provided by the Appellant either through records or during deposition to substantiate its allegation that the Respondent was himself trading in his account. However, as maintained and substantiated by the Respondent through logs of communication over mobile phone with the Appellant and submitted along with the Appeal, it is observed that barring a very few messages from him before the commencement of business hours on 23-11-2011, all the other logs originated from Appellant's servers only. It is evident that the Respondent neither placed orders nor authorized the Appellant to trade on his account. All the orders and trades were originated and executed unilaterally by the Appellant without any authority and consent from Respondent. The role played by the Appellant and disowning the responsibility for the activities and dealings of its employees are contrary to the provisions of the Rules, Regulations and By-laws of the SEBI, BSE and NSE (SEBI, 2012) [3].

The Appellant has not been fair and honest in dealing with the Respondent and has come out with to support its act of deficiencies and gross negligence in rendering service. It was purely lack of due diligence and greed on the part of the Respondent falling into the trap laid by the Appellant. The transactions had been actually carried out by the dealers assigned to the Respondent by the Appellant. The evidence available and those on records including the depositions from both the contestants suggest that the Respondent had become a victim partly of his own greed and excessive trust on the Appellant's credentials. It is concluded that Mr Niraj Reddy the Relationship Manager of Mumbai Capitals Ltd., marketed the Portfolio Management Scheme, Wealth Management Scheme, Capital Pro- 
tection scheme, discretionary trading arrangement to the Respondent without specifying an arrangement and misguided as trading Account. Accordingly, Mumbai Capitals charged Rs 500,000 towards subscription fee. There is no such subscription fee concept in the NSE trading. The brokerage is charged on the basis of trade price and total value of trade. Appellant has neither license nor permission from SEBI or NSE to undertake such activities.

MCL documented under Clause 10 of the memorandum of understanding (MoU) with its clients and took signatures of clients states that "It is clearly understood and agreed to by client that no service, facility in the nature of portfolio management, advisory services are contemplated under the agreements and MoUs between the client and MCL. No person working for or under MCL, whether dealer, relationship manager, sub broker or authorized person is permitted to provide any services and facilities except that of order placement in trading system (subject to imitation stated above) upon the directions of client". It indicates that few of its employees, dealers, sub-brokers are indulging in such schemes/activities. It is one of the clauses of the MOU that was entered by the Respondent. It is evident and clear from the foregoing, that the arrangement of the Appellant with the Respondent was one of such activities and not trading account. The Respondent was advised and told he need not respond to contract notes, confirmations and other correspondence and these are sent only to meet and comply with the NSE's requirements (SEBI, 2010) [1]. In this case matter, the issue is not related to unauthorized trades. The issue is pertaining to the unauthorized activities of Mumbai Capitals Ltd under head of trading account. Under discretionary trading arrangement, the Respondent was supposed to be silent and only observer to the actions of Appellant and non responsive to the contract notes, bills and ledger copies. Respondent was orally promised by the Appellant to generate higher profits with the help of so called experts in Futures \& Options trading. This was tricky issue. Orally it was an understanding, and arrangement that Respondent was promised to generate higher profits and MCL wanted to generate brokerage income to itself at the cost of Respondent.

Respondent was guaranteed by the Reddy, an employee of MCL to give some time to recoup the losses suffered/incurred in the account by emails on April 11, 2013 and June 16, 2012. Mr Reddy, Relationship Manager of Appellant requested Respondent to give two months time to recover his money from the market. In his second e mail on June 16, 2012, Reddy requested for 30 days time to recover maximum amount in the Respondent's account and same would be handled experts. The Appellant neither attempted to compensate the losses incurred by its dealers nor provided the profits as promised by its employees. Appellant was silent on this issue. It neither responded positively nor provided justifiable answer. As submitted by the Appellant, it had made two payouts as requested by the Respondent. However, Appellant could not provide any evidence of the Respondent's request for such pay outs. Generally, pay out takes place for full 
amount of balance and due. Appellant could make full pay out of Rs 3,900,000 instead of Rs 400,000 as requested by the Respondent on 2-12-2011. The second pay out was made for Rs 120,000 on February 03, 2012. It clearly proved and demonstrated that it is not a normal trading account but it is a combination of Portfolio Management Scheme, Capital Protection Scheme, and discretionary trading arrangement. In view of this, it is not relevant and proper to consider the contact notes, daily margin statements, and accounts that were sent by the Appellant.

It is not the case of unauthorized trades as contended by the Respondent and as concluded by the sole arbitrator. It is clear, classic and fit case of unauthorized activities by the Appellant. The Appellant is neither allowed nor permitted to undertake such activity or combination of activities such as Portfolio Management scheme, Wealth Management scheme, Capital Protection scheme, discretionary trading arrangements etc. The Appellant has not brought anything new other than repeating what it had already pleaded in its submissions before the sole Arbitrator. The allegations of the Appellant in the Appeal are of its bias. The Appellant cannot disown its fiduciary responsibility in respect of omissions and commissions of its employees and dealers. Appellant has to compensate the Respondent as it would be in the best interest of equity and natural justice. The Respondent failed to monitor his account and take timely actions to prevent losses.

\section{Recommendations (Award)}

In view of the submissions, documents and hearings of both parties, it is in the interest of justice, law and equity and good conscience, the Appellant Tribunal passed the award. The Appeal is rejected and dismissed. The Appellant Arbitral Tribunal also set aside the award passed by the sole arbitrator and the Appellant, Mumbai capitals Ltd. is directed to pay an amount of Rs 3,500,000 (Rupees thirty five lakhs only) to the Respondent towards refund of his deposit. Parties have to bear their own costs. This award was passed at Hyderabad.

\section{The Way Forward}

The stock exchanges of the country and regulatory authorities have to identify and appoint arbitrators not only from the legal field but also look for experts with domain knowledge of the securities market and capital market operations. The panel of arbitrators while analyzing the case matter and passing the award, will be better equipped to pass the right, fair and equitable award in the light principles of natural justice. The arbitrators have to look into the trading procedures and not only to understand the rules and regulations of the Stock Exchange but also trading practices, business development strategies and marketing techniques of the trading members.

\section{References}

[1] SEBI's Circular No.CIR/MRD/DSA/29/2010, Dated August 31, 2010. 
[2] The Arbitration and Conciliation Act, 1996 (As Amended by the Act No. 3 of 2016).

[3] SEBI 2012, Rights and Obligations of Stock brokers, Sub Brokers and Clients.

[4] https://www.nseindia.com 


\section{Appendix-I}

\section{National Stock Exchange of India Ltd}

The National Stock Exchange (NSE) was incorporated in 1992. It was recognized as a stock exchange in April 1993 and commenced operations in June 1994 in wholesale debt market (WDM). It launched the cash market segment in November 1994. The NSE is the fourth largest stock exchange in the world by equity trading volume. It is ranked as the largest stock exchange in India in terms of total and average daily turnover for equity shares. NSE has a fully-integrated business model comprising exchange listings, trading services, clearing and settlement services, technology solutions and financial education offerings. It is committed to the values of integrity, trust, respect and care for the individual, passion for excellence, and teamwork. NSE provides equity and equity linked products, derivatives, and debt products through its different trading platforms (https://www.nseindia.com) [4].

\section{Stock Exchange’s Arbitration Procedure}

1) Arbitration: Arbitration (the Arbitration and Conciliation Act, 1996) [2] is a quasi judicial process of settlement of disputes between two parties i.e., between a trading member and an investor. Arbitration aims at quicker legal resolution for the disputes. When one of the parties feels that the complaint has not been resolved satisfactorily either by the other party or through the complaint resolution process of the Exchange, the parties may choose the mechanism of arbitration. All disputes arising out of transactions done on the Exchange by the parties or anything incidental thereto are under the purview and eligible for arbitration mechanism provided by the exchange.

2) Arbitration Framework: Arbitration is governed by rules, bye laws, regulations \& circulars issued by the Exchange and SEBI, from time to time. The arbitration is conducted in accordance with the principles of natural justice and rules and regulations as may be prescribed by the Exchange. If the claim value is more than Rs. 2.5 million a panel of three arbitrators is constituted and if the claim value is less than Rs. 2.5 million, a sole arbitrator is appointed.

3) Arbitration for Margin Trading: The arbitration mechanism of the exchange would not be available for settlement of disputes, if any, between the client and members, arising out of the margin trading facility. However, any disputes relating to transactions done on the exchange, whether normal or through margin trading facility, shall be covered under the arbitration mechanism of the exchange.

4) Statement of Claim and Defense: In arbitral proceedings, the most important documents are statement of claim/case filed by the Applicant/Claimant and the statement of defense submitted by the Respondent. The party who moves for arbitration and sets out claims is called Claimant/Applicant and the person against whom the claim is filed is called respondent, the opposite party. While the Claimant files a claim statement which contains details of his griev- 
ances, the Applicant of dispute, description of the case, summary of events leading to the dispute, basis of arriving at the claim amount and relief sought through arbitration. Entire dispute described in date wise sequence of events which took place between the investor and the trading member needs to be described. Statement of case is the first source of information which the sole arbitrator/arbitrator panel refers to in advance to understand the case and hence it is very significant. The respondent meets/attacks with his statement of defense. Respondent counters the claim with the details given in the statement of defense. Further, both the parties also may file the necessary documents in support of their respective claims and defense statements. The Respondent may also set a counter claim against the claimant. The contentions of the respective parties obviously must be supported by proper evidence (the Arbitration and Conciliation Act, 1996) [2].

\section{5) Hearings and Written Proceedings}

After filing of the necessary papers, the next important part of the arbitral proceedings is the personal hearings of the case and considering the documentary evidence. The normal procedure adopted is that after presentation of claim statement and defense statement, the arbitral tribunal hears the parties and receives written arguments. Section 24 of the Arbitration and Conciliation Act, 1996 contains the relevant provisions pertaining to hearings and written proceedings.

\section{Award}

Award is a judgment passed by the arbitration panel which gives a direction to either of the disputing parties as regard to their claim raised in the arbitration matter. The arbitral award includes an interim award. An arbitral award shall be made in writing and shall be signed by the members of arbitral tribunal. Section 31 of the Arbitration and Conciliation 1996, prescribes the form and contents of an arbitral award. The arbitrator shall make an award within four month or such time as may be specified by the Exchange after entering into the reference. The decision of the arbitrator shall be by way of an award in writing which shall clearly state the reasons for arriving at such decision. Such an award shall be final and binding on the parties to the reference. After the arbitration award is made, a signed copy shall be delivered to each party. The Arbitrator may at any time during the arbitration proceedings, make an interim arbitration award on any matter with respect to which he may make a final arbitration award. Under Section 35 of the Arbitration and Conciliation Act 1996, an arbitral award shall be final and binding on parties as regards the matter referred to and decided by the arbitral tribunal. The award once passed by the arbitrator is final and binding on the parties unless challenged before a higher forum. In case of certain corrections or interpretation required to be made in the award, any party to arbitration can file application with the Exchange under Section 33 of Arbitration and Conciliation Act, 1996 [2] for correction or interpretation of award, within a 
month from the date of receipt of award. The Exchange will forward the application to the concerned arbitrator/s. In case the arbitrator/s feel/s the requirement of correction/interpretation in the award as requested, he/she can do so by passing a separate order.

\section{Appeal on the Arbitral Award}

Even though there is no provision for appeal against an arbitral award, against any order of the court under Section 34 of the Arbitration and Conciliation Act, 1996 [2], an appeal lies to the Appellate Court under Section 37 of the Act, 1996 [2]. The aggrieved party of the award may approach the Exchange with an application in the prescribed format for appeal before the appellate arbitrators, along with applicable deposit, within a period of 30 days from the date of receipt of the arbitral award or the aggrieved party can challenge the award U/S 34 of Arbitration and Conciliation Act, 1996 in the district civil court. When the appellate arbitral award is passed in favour of investor:

a) Trading member may settle the award and confirm the same to the Exchange; or

b) Trading member may challenge the appellate arbitral award under Section 34 of the Arbitration and Conciliation Act, 1996, can file petition under section 34 of the Arbitration and Conciliation Act 1996 [2]. The appellate arbitrator panel hears both the parties and passes an Appellate Arbitral Award. The appellate arbitral award may set aside decision of the original arbitral award or uphold the same. 